\title{
Nutritional Status and Knowledge about Nutrition during Pregnancy among Pregnant and Postpartum Women
}

\author{
F Salim', N Begum²
}

\begin{abstract}
Objective : To assess the nutritional status and the level of knowledge about nutrition during pregnancy among pregnant and postpartum women attended community clinics in selected villages.
\end{abstract}

Methods : This descriptive, cross-sectional study was done in three selected villages of Sirajganj, Kishoreganj and Tangail districts during July 2014. Fifty six pregnant and 46 postpartum women were selected from community clinics by purposive sampling technique. Data were collected through face to face interview by a pretested questionnaire. Height and weight were measured to calculate BMI health workers of community clinic.

Results : The results of the study revealed significant number (23.5\%) of pregnant women were found to be underweight by calculating the BMI. However, knowledge about the consequences of malnutrition in pregnancy, and the amount and types of food to be taken during pregnancy was found unsatisfactory. The level of education and occupation were not significantly associated with nutritional status of the respondents.

Conclusion : The study revealed that high percentage of rural mothers was malnourished and the knowledge about nutrition during pregnancy was found unsatisfactory. Therefore, implementation of nutritional programs with specific emphasis on nutritional education in pregnancy during the antenatal visits is considered essential for rural women.

Keywords : Pregnant women, Malnutrition, Nutritional status.

\section{Introduction}

Malnutrition is inadequate intake of nourishing food or consumption of a particular type of food that has little or no nutritive value. ${ }^{1}$ According to Bangladesh Demographic and Health Survey Report, 2011, the prevalence of malnutrition in Bangladesh is among the highest in the world. ${ }^{2}$ Malnutrition is like an iceberg; most people in the developing countries live under the burden of malnutrition. Pregnant women, nursing mothers and children are particularly vulnerable to the incidence of malnutrition. The adverse effects of maternal malnutrition are maternal depletion, low birth weight, anaemia, toxiaemias of pregnancy, post partum hemorrhage which result in high mortality and morbidity. ${ }^{3}$

During pregnancy diet should contain more protein, iron, iodine, Vitamin-A, folate, and other nutrients. Nutritional demand increases in the second and particularly the third trimester of pregnancy. Undernutrition, both before and during pregnancy, causes intrauterine growth retardation and is one of the major reasons for the high LBW (according to WHO report $22 \%)^{1}$ prevalence in the country. Low birth weight is more common among adolescent mothers. Deficiencies of certain nutrients are associated with maternal complications and death, fetal and newborn death, birth defects, and decreased physical and mental potential of the child. ${ }^{4}$

Women and children suffer from one or more forms of malnutrition including low birth weight, wasting, stunting, underweight, Vitamin-A deficiencies, iodine deficiency disorders and anemia. Malnutrition not only affects individuals but its effects are transmitted from one generation to another as malnourished mothers give birth to infants who struggle to develop and thrive. If these children are girls, they often grow up to become malnourished mothers themselves. Globally, malnutrition is attributed to almost one-half of all child mortality. ${ }^{5}$

Micronutrient deficiencies especially iron and folic acid deficiencies that result in nutritional anemia and neural tube defects in newborns remain a public health problem in Bangladesh. Coverage of pre- and postnatal iron and folic acid supplements is very low only $15 \%$ of pregnant women in rural areas take at least 100 tablets during pregnancy. Low compliance rates and low coverage of antenatal services made it difficult to maintain proper nutrition during pregnancy. $^{6}$

Under-nutrition (body mass index less than 18.5 $\mathrm{kg} / \mathrm{m}^{2}$ ) in non-pregnant women in the country, declining from $54 \%$ in $1996-1997$ to $34 \%$ in 2004 and $24 \%$ in 2011, is still very high ${ }^{7,8,2}$. About six in ten ever-married women (59 percent) have a normal BMI, 24 percent are undernourished (BMI less than 18.5), and 17 percent are overweight (BMI 25 or higher). ${ }^{2}$

\section{Materials and methods}

This descriptive cross-sectional study was conducted in July, 2014. Data were collected from three selected villages of Sadar upazila of Sirajganj, Bhuapur Upazila of Tangail and Sadar upazila of Kishoreganj districts. Study population were total 102 childbearing mothers of which 56 were pregnant and 46 gave birth within 42 days at the time of data collection; selected purposively from the study area. They were selected from those who registered for the ante natal checkups in Community Clinics. Data were collected by direct 
interviewing of the selected women according to the pretested structured questionnaire.

Following Measurements of the respondents were recorded

Height : Height in centimeters was marked in the wall of community clinic with the help of a measuring tape. After removing the footwear women were asked to stand against the wall with heels together and head straight. Height was recorded to the nearest $1 \mathrm{~cm}$.

Weight : Weight was recorded by a bath room scale. It was calibrated regularly. BMI, a simple index to classify underweight, overweight and obesity, was measured from height and weight.

Data processing and analysis : The data were analyzed by preparing master sheet. Tables of descriptive statistics were prepared to present and analyze the major findings as per the study objectives by using statistical soft ware SPSS version 16

\section{Results}

The socio-demographic information regarding age group, education, occupation and monthly income were as follows:

$\begin{array}{lcc}\begin{array}{l}\text { Table-I : Distribution of the socio-demographic characteristics; } \mathbf{~}=\mathbf{1 0 2} \\ \text { Age group }\end{array} & \begin{array}{c}\text { No of respondents } \\ \text { Percent }\end{array} \\ \text { 20-25 years } & 22 & 70.6 \\ \text { 26-30 years } & 8 & 21.6 \\ \text { 30+ years } & & 7.8 \\ \text { Mean = 23.32; (SD = } \pm 4.887) & & \\ \text { Educational qualification } & 9 & \\ \text { Illiterate } & 43 & 8.8 \\ \text { Primary } & 46 & 42.2 \\ \text { Secondary } & 4 & 45.1 \\ \text { Higher secondary } & & 3.9 \\ \text { Occupation of respondents } & 98 & \\ \text { House wife } & 1 & 96.1 \\ \text { Farmer } & 1 & 1.0 \\ \text { Day laborer } & 2 & 1.0 \\ \text { Service } & & 2.0 \\ \text { Monthly income } & 17 & \\ \text { Taka 4,000 } & 45 & 16.7 \\ \text { Taka 4,001-6,000 } & 30 & 44.1 \\ \text { Taka 6,001-8,000 } & 5 & 29.4 \\ \text { Taka 8,001-10,000 } & 5 & 4.9 \\ \text { Taka 10,000+ } & & 4.9 \\ \text { Mean = 6,164.71; (SD = } 2,498.14) & \end{array}$

Table- II : Distribution of the respondents by weight and height Weight No of respondents Percent Height No of respondents Percent $\begin{array}{llllll}40 \mathrm{~kg} & 20 & 19.6 & 140 \mathrm{~cm} & 11 & 10.8\end{array}$ $\begin{array}{llllll}41-45 \mathrm{~kg} & 30 & 29.4 & 140-150 \mathrm{~cm} & 33 & 32.4\end{array}$ $\begin{array}{llllll}46-50 \mathrm{~kg} & 22 & 21.6 & 150-160 \mathrm{~cm} & 35 & 34.3\end{array}$ $\begin{array}{llllll}51-55 \mathrm{~kg} & 14 & 13.7 & >160 \mathrm{~cm} & 23 & 22.5\end{array}$ $\begin{array}{llllll}>55 \mathrm{~kg} & 16 & 15.7 & - & -\end{array}$ Total $\quad 102 \quad 100.0$

$40 \mathrm{~kg}$ and the height of $10.8 \%$ of them was below $140 \mathrm{~cm}$. The mean weight and height of the respondents were $47.6 \mathrm{~kg}$ and157.7 cm respectively

Table-III : BMI of the respondents

The study showed that among 102 respondents 24(23.5\%) were underweight, 62(60.8\%) were within normal range and $16(15.7 \%)$ were overweight (Table-III).

$\begin{array}{lcc}\text { BMI } & \text { No of respondents } & \text { Percent } \\ \text { Under weight }(<18.5) & 24 & 23.5 \\ \text { Normal }(18.5-34.5) & 62 & 60.8 \\ \text { Over weight }(>24.5) & 16 & 15.7 \\ \text { Total } & 102 & 100.0\end{array}$

Among 102 respondents, 79(77.5\%) took iron and folic acid during pregnancy; $22.5 \%$ did not take.(Table-IV).

\section{Table-IV : Respondents by intake of iron \& folic acid during pregnancy}

$\begin{array}{ccc}\text { Iron and F Acid } & \text { No of respondents } & \text { Percent } \\ \text { Yes } & 79 & 77.5 \\ \text { No } & 23 & 22.5 \\ \text { Total } & 102 & 100.0\end{array}$

Association between education and occupation of the respondents with nutrition status during pregnancy was found not significant (Table-V).

Table-V : Relationships between education and occupation of the respondents with nutritional status during pregnancy

$\begin{array}{lcccc}\begin{array}{l}\text { Maternal factors } \\ \text { Education }\end{array} & \text { Malnourished } & \text { Normal } & \text { Total } \mathbf{N}=\mathbf{1 0 2} \text { Significance test } \\ \begin{array}{l}\text { Illiterate or Primary education } \\ \text { Higher education }\end{array} & 12(23.1) & 40(76.9) & 52 & \mathrm{p}=0.93 \\ \begin{array}{l}\text { Occupation } \\ \text { Housewife }\end{array} & 12(24.0) & 38(76.0) & 50 & \\ \text { Others } & 23(23.5) & 75(76.5) & 98 & \mathrm{p}=0.94 \\ \text { Total } & 1(25.0) & 3(75.0) & 4 & \\ & 24(23.5) & 78(76.5) & 102 & \end{array}$

Among all respondents, 28 (27.4\%) knew that malnutrition during pregnancy may cause low birth weight, 38 (37.2\%) knew that it may cause generalized weakness (vertigo, tiredness, etc.); and $17(16.6 \%)$ told that it may cause repeated infection of the mother.25 $(24.5 \%)$ mentioned malnutrition during pregnancy can cause abortion or birth of baby before due date (Table-VI).

\section{Table-VI : Distribution of the respondents by knowledge on effects of malnutrition during pregnancy}

\section{Variables}

Low birth weight

Generalized weakness

Repeated illness(lowered immunity)

Abortion or premature delivery

Multiple responses

Regarding knowledge about which variety of food can give more nutrition during pregnancy, $24(11.8 \%)$ mentioned about rice, 64(31.5\%) about milk/egg/Meat/Fish and 70 (34.3\%) about vegetables. $46(22.4 \%)$ respondents had no knowledge about the type of foods. (Table-VII). 


$\begin{array}{lcc}\begin{array}{l}\text { Table-VII : Distribution of the respondents by knowledge on type of } \\ \text { nutritious food during pregnancy } \\ \text { No of respondents }\end{array} & \begin{array}{c}\text { Percent } \\ \text { Type of nutritious food }\end{array} \\ \text { Rice } & 24 & 11.8 \\ \text { Milk/egg } & 64 & 31.5 \\ \text { Vegetables } & 70 & 34.3 \\ \text { Don't know } & 46 & 22.4 \\ \text { Total } & 204 & 100.0\end{array}$

Multiple responses

Regarding knowledge on effects of nutritious foods during pregnancy, $28(27.5 \%)$ respondents reported that baby's weight will be normal, $4(3.9 \%)$ said baby's weight will be low, $68(66.7 \%)$ mentioned baby will be overweight. $2(2 \%)$ respondents had no knowledge regarding this. (Table-VIII)

\section{Table-VIII : Knowledge on effects of nutritious foods taken during pregnancy by the respondents}

\section{Effects of nutritious food}

Baby's weight will be normal

Baby's weight will be low

Baby will be overweight

Do not know

Total

No of res

Percent

28

4

68

2

02
27.5

3.9

66.7

2.0

100.0

\section{Discussion}

This cross-sectional study was conducted with a view of assessing the nutritional status and the level of knowledge about nutrition during pregnancy among pregnant and postpartum women attended in the community clinics in selected villages.

Regarding socio-demographic data, $45 \%$ of the respondents had secondary education, most of them (about 96\%) were housewives and monthly income of most respondents (about 44\%) were between Tk.4,000-6,000. The socio-economic findings were more or less similar to the study by Hossain et al ${ }^{9}$.

In the present study $23.5 \%$ of the respondents were suffering from malnutrition (BMI <18.5). In some studies it was found that the average weight and height of Bangladeshi women were $42 \mathrm{~kg}$ and 154 $\mathrm{cm}$ respectively 10,11 In a survey of 26,424 pregnant women it was found that $35-38 \%$ had BMI less than 18.5 , weighted $48-49 \mathrm{~kg}$ and over $50 \%$ were suffering from severe iron deficiency anemia 10 . The level of education was not found significantly associated with BMI of the respondents( $p>0.05)$. Similarly, occupation of the respondents was not found to be significantly associated with their BMI ( $p>0.05)$, though a significant association was expected in both the cases.
Regarding knowledge about the effects of malnutrition on pregnancy $27.4 \%$ knew that malnutrition associated with low birth weight baby and $37.2 \%$ had idea that pregnancy causes general weakness, $16.6 \%$ knew that lower mother's immunity. Some $24.5 \%$ had the perception that malnutrition during pregnancy is one of the main reasons for abortion. In a study conducted in rural Nigeria, the majority of the participants strongly agree that maternal malnutrition may cause low birth weight ${ }^{12}$.

Most of the pregnant women (about 34.3\%) reported vegetables as the most nutritious food during pregnancy rather than protein rich foods like milk, egg, fish or meat. Regarding effects of nutritious food on the unborn child, about $66.7 \%$ informed that the baby would be overweight if more nutritious foods are taken during pregnancy. This was supported by Landman's article ${ }^{13}$. These may also reflect lack of nutritional education.

Conclusion : This study provided an important in formation is that high percentage of mothers was malnourished and the knowledge about nutrition during pregnancy was found unsatisfactory. A longitudinal study on a large scale including all the variables related to nutritional status of the women is required to obtain further information to find out the real situation of nutritional status during pregnancy.

\section{References}

1. World Health Organisation: Report on child and maternal nutrition http://www.who.org/ bangladesh/Child_and_Maternal_Nutrition

2. Bangladesh Demographic and Health Survey 2011, NIPORT, January 2013; 185, 189

3. Park K, Park's Text Book of Preventive and Social Medicine, M/s Banarsidas Bhanot, Jabalpur: $21^{\text {st }}$ edition $2011,(10) 483$

4. UNICEF report on child and maternal nutrition. www.coregroup.org/ storage/.../Maternal Nutrition Dietary Guide_AED.pd;

5. http://www.unicef.org/bangladesh/Child_and_Maternal_Nutrition

6. Nutrition Surveillance Programme; Helen Keller International/ IPHN 2006

7. Bangladesh Demographic and Health Survey, 2000.

8. Bangladesh Demographic and Health Survey 2004.

9. Hossain et al.Nutritional Status of Pregnant Women in Selected Rural and Urban Area of Bangladesh; Journal of Nutrition Food Science, 2013, 3:4

10. Nessa N. and Mahmuda MA. Situation of women in Bangladesh: their health and nutritional status and support to breast feeding (abs.). Nutrition Society of Bangladesh. 7th Bangladesh National Conference (Special publication) March 1997:89.

11. Talukder MQK. Maternal nutrition versus foetal infant health. Bangladesh Paediatrics. 1983; 7 (3\&4): 68-70.

12. Jacinta A. Opara, Helen E. Adebola, Nkasiobi S. Oguzor and Sodienye A. Abere. Malnutrition During Pregnancy among Child Bearing Mothers in Mbaitolu of SouthEastern Nigeria.

13. Landman JP. Food fads in pregnancy. Postgrad Doct-Middle East 1991;14:48-52 